\title{
Doing more with less at Ariens: A leadership and transformation case study
}

\author{
Jennifer K. Hartwell, Ph.D. \\ School of Business \\ Western New England College \\ 1215 Wilbraham Road \\ Springfield, MA 01119 \\ Jh281715@wnec.edu \\ (860) 232-1101
}

\author{
George Roth, Ph.D. \\ Lean Aerospace Initiative \\ Massachusetts Institute of Technology \\ 77 Vassar Street, 41-205 \\ Cambridge, MA 02139 \\ groth@mit.edu \\ (617) 253-8407
}

Is this a First -time CASE Submission (i.e., your first submission as an author to a CASE conference)? YES

Did a Mentor help you write this case? NO 


\section{Doing more with less at Ariens: A leadership and transformation case study*}

\section{Table of Contents}

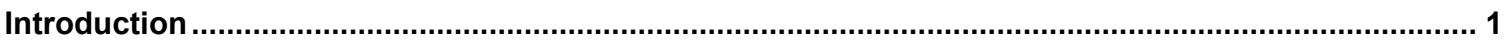

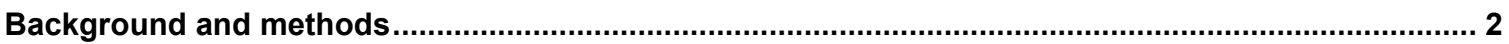

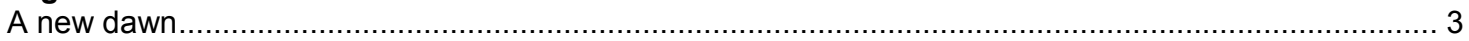

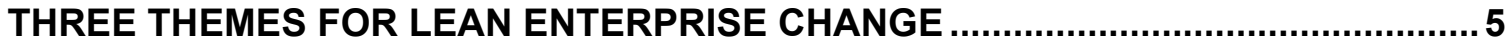

1. Conditions for Lean: Leaders created trusting conditions that persevered through adversity .......5

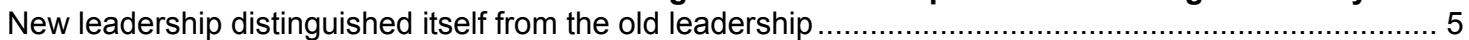

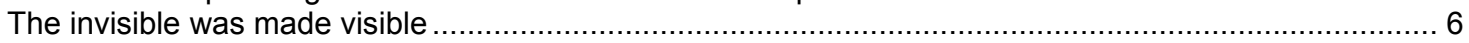

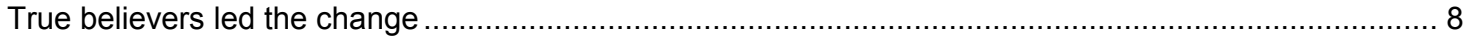

Trust in leadership

Flexibility and perseverance enabled Ariens to adapt to bumps in the road...................................10

2. Continual Improvement: Initial changes created benefits and set off a virtuous learning cycle......11 Initial tangible changes showed that this effort was different..........................................................12 Lean success became evident through the multi-faceted outcomes of business and personal results .....14 Greater benefits came from aligning to value streams ...................................................................16

3. Lean Change Methods: Leaders setting goals, communicating, and giving feedback changed the culture

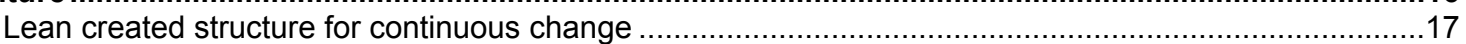

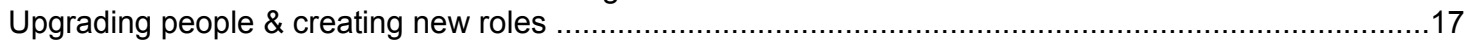

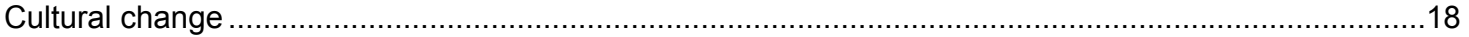

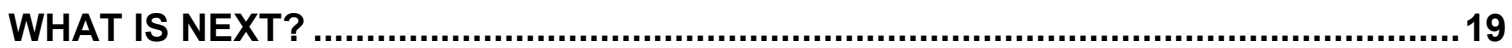

APPENDIX A COMPARATIVE FINANCIAL \& OPERATIONAL RESULTS ..................22

APPENDIX B ARIENS COMPANY HISTORY .................................................... 24

ENDNOTES

\footnotetext{
* This material is based on research sponsored by the Air Force Research Laboratory (under agreement number FA8650-05-2-5706) and a consortium of other government and aerospace industry members. The U.S. Government is authorized to reproduce and distribute reprints for Governmental purposes notwithstanding any copyright notation thereon. The views and conclusions contained herein are those of the authors and should not be interpreted as necessarily representing the official policies or endorsements, either expressed or implied, of Air Force Research Laboratory, the U.S. Government or other consortium members.
} 


\begin{abstract}
This case study illustrates the challenges of organizational change and transformation. The company studied, Ariens Company, used "lean" principles and methods in making these changes. As a manufacturer of snow and lawn equipment, the promises of lean manufacturing from the automotive industry were very appealing to Ariens' management. Indeed, the company faced a crisis in 1998 - overproduction had left it with excessive inventory, and its costs were too high to sell its products through retail channels. Distribution costs ate most of the possible profit margins in selling through dealers. The company needed sweeping changes - a financial restructuring, change in its distribution system, reduction of inventory, new production methods, and lower cost and better quality products. The company as a whole, from senior leadership to shop floor workers, needed to work together to achieve these changes. The thinking, process and sequence of top, middle and front-line management changes, is the focus for this case study of lean transformation.

In June 2005, we made a three-day visit to Ariens where we formally interviewed eleven people - from the CEO to factory workers. We also toured the plant, attended a lean meeting, engaged in many informal discussions, and reviewed secondary sources. Three themes were derived from the data and illustrate what we learned studying Ariens' lean program. This case is important for managers and students studying organizational change, leadership, or lean manufacturing because it provides an example of a set of changes, using and extending lean manufacturing principles, which accumulated into significant performance improvements and from which all managers and students could learn.
\end{abstract}




\section{Introduction}

This case study reports on Ariens' lean transformation - a series of changes using lean principles ${ }^{1}$ and extending them beyond manufacturing settings. ${ }^{2}$ It provides an example of a set of changes that accumulated into significant performance improvements.

It is part of a series of case studies

undertaken by researchers at the

"School of Management" and

"School of Engineering

Aeronautics and Astronautics".

We have focused on developing,

testing and studying the

application of lean principles

originating in studies of the

Japanese automotive industries.

Lean: The term "lean production" was coined by researchers studying automotive companies; they found that the techniques developed by Japanese companies were superior to American and European craft and mass production techniques. In terms of the relationship between human resources and technology, "lean" relied on teams of workers with flexible automation. Researchers found that lean factories produced large volumes of products with half the human effort, half the manufacturing space, half the investment in tooling, half the engineering hours and in half the new product development time compared to mass production factories. Lean requires much less inventory than traditional methods, as production is based on flow and pull - delivering what the customer wants when it is wanted. Subsequent research has elaborated on these characteristics of lean and articulated the progression of lean from operations to enterprise levels.

Ariens is somewhat different from aerospace companies. It is located in a rural part of

Wisconsin, has close to 800 fulltime and over 300 seasonal employees and is

substantially smaller in terms of annual revenues than most aerospace companies. The

business is seasonal, making consumer and professional-grade snow blowers and lawnmowers.

As a medium-sized company, Ariens enabled us to study its lean change process in a less complex business and technical context than large aerospace conglomerates.

Our specific interests are on the elements of the leadership and change processes that enable the successful application of lean principles and practices across the organization and in its enterprise - the customers and suppliers along its value steam. 


\section{Background and methods}

In June 2005, following a number of telephone interviews, exchange of

information, and archival research, we made a three day visit to Ariens. We conducted eleven open-ended interviews - from the CEO to factory workers - that lasted from fortyfive minutes to one hour, toured the plant, had several informal discussions, and attended lean meetings. We developed and continually refined a time line of the change efforts, and asked people to report on their involvement in and assessment of these changes. We took detailed notes during these interviews, and then coded and content analyzed these notes to develop several major themes from these data. The case is organized according to these three themes, each of which traverses the chronology of Ariens efforts, as shown in Figure 1. Before reporting on changes, we set the stage for the transformation and its outcomes as of June 2005 .

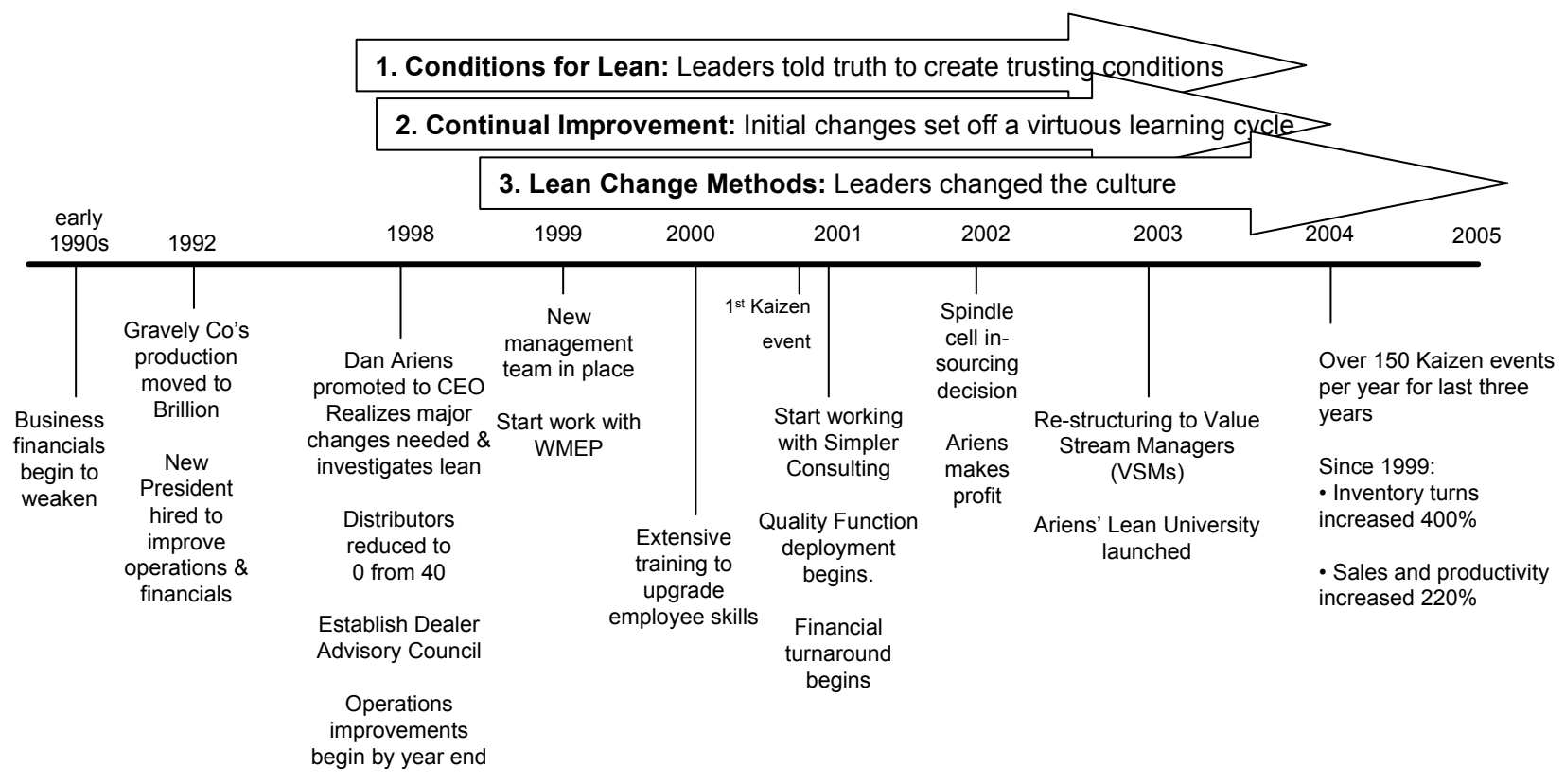

Figure 1. Mapping of themes on Ariens' change milestones 


\section{A new dawn}

There was no ray of sunlight visible as people made their daily drive through darkness on long rural roads across snow-covered cornfields to get to Ariens' [pronounced â•rānz] mid-west factories. The fluorescent lights of the factory glared upon the assembly line operators as they walked through the building gates to start their workday. They knew that they were productive: there were stacks of products wherever there was a place for them in the factory. These were good jobs that the operators had, but it was hard work. They were constantly under pressure from management to produce more, yet while they were doing that they all wondered just where they could even put more of the new mowers.

It was $5 \mathrm{AM}$ on the $15^{\text {th }}$ of March 1998, when workers saw what surely must be an apparition. It was Dan Ariens, son of the chairman and great-grandson of the founder, walking through the factory greeting their colleagues. He said he was back; he would be taking over as the new president. Everyone knew him well; he had grown up here, gone to high school with some of them, worked with them on the floor during his college vacations, and then in various company management positions. But, five years ago he left the area to move to Indiana to run a spare parts business. He was largely gone and mostly forgotten. Was that really him walking through the factory, and why was he back?

Family members ran Ariens until Dan's father, Michael Ariens, himself an excellent craftsman and manufacturing engineer, stepped aside as President to become the Chairman of the Board. After several years of not being profitable, he brought in a new president as a turnaround manager to put the company on a firmer financial footing. It had all gone well at first; sales were at record levels, and the factory was running at full 
tilt. But, while this new President had met his objectives, it was how he did it that bothered Dan. Yes, sales were at record levels, but there was too much inventory, overall costs were too high, and quality was not nearly where it should have been. Dan was not convinced that they were on a firmer financial footing, and many of the people he knew in the plant were unhappy with how they were treated. What was troubling from a distance turned out to be worse than expected when Dan took the helm and looked more carefully. Ariens achieved its efficiencies and low overhead rates by producing at record levels, and filling the factory, warehouse, and dealer pipelines with inventory. The company was now suffocating on its inventory! The compensation calculations in the previous President's contract gave him and his management team members huge bonuses for this production. This situation directed Ariens towards a recovery efforts using lean production; in part to insure that they would never find themselves in that excess inventory situation again.

While lean efforts were getting started, a new management team was formed. Loans were renegotiated with the bank, and intermediaries - distributors - had to be eliminated as a cost in reaching Ariens' dealers and their customers. Many of the products in inventory required re-furbishing. For some products, nothing new was produced for over a year because there was that much of it in inventory.

Seven years later, the company had made significant strides. It was on stable footing, with significant operational and financial improvements. Between 1999 and 2005 , productivity increased over $200 \%$, inventory turns improved over $300 \%$, safety incidents have been halved (from their 2001 peak), sales increased over $200 \%$, and profits improved by a factor of ten (see Appendix A for more details). In 2006, Ariens was named Wisconsin Manufacturer of the Year by Wisconsin Manufacturers and 
Commerce. Ariens' managers attribute these gains to its lean program efforts. How they organized and made these changes is the focus of this case study.

\section{Three themes for lean enterprise change}

\section{Conditions for Lean: Leaders created trusting conditions that persevered through adversity}

There was no question that Ariens had a big crisis on its hands. If changes were not initiated quickly, the company would falter. The new lean practices at Ariens received unwavering support from the company's president, Dan Ariens. Beyond the need for a burning platform and top management support - Ariens' experience suggests a particular type of leadership communication and crisis management technique that enables successful change. Dan Ariens firmly established himself as the leader, brought in a new leadership team, and made the crisis facing the company visible to all employees. As such, Ariens provides an example of what it specifically means for a change process to have "top management support."

\section{New leadership distinguished itself from the old leadership}

The turnaround that the company needed to be profitable looked brilliant from 1993 to 1998 . However, when Dan took over in 1998, he found that the company was in serious trouble. Dan staffed a new leadership team that was different from the past. He spoke about the past and future as two completely separate entities, admitting the need for change, thereby introducing hope and freeing his employees from beliefs like "that's

just the way it is." Dan let the workers know he was in charge, the integrity that his name stood for, by entering through the factory at the start of the first shift on the day that he 
returned. This symbolic entry set a tone for the future... "we have principles, we will follow our principles, and ...we are in a hell of a lot of trouble!"

In his first month, Dan terminated three vice-presidents and twelve director level managers... "It was the wrong culture. It was dictatorial, 'Do it my way, damn it!'” Others described these managers as uncaring and disrespectful of humanity. One longtime manager explained that the financial orientation resulted in his being handed a list of people who he was to fire because the company had had a bad month. With out the opportunity to provide input, he was told to fire the employees on the list.

Ariens had always been a family company where employees were cared for, the environment was open, and there was a close-knit feeling. The legacy of leaders created what might be a benevolent patriarchy, in a good sense, in that it sought to balance its benefits to customers, suppliers, investors, owners, workers, and community. Dan was the fourth generation of family management and strived for an open company culture that valued employees while operating at world-class productivity, quality and innovativeness. He created a list of core values that became his guiding light back to family-business values: "Be honest, Be fair, Keep our commitments, Respect the individual, and Encourage intellectual curiosity." Dan was committed to creating a "thinking, learning, and problem solving culture." In the face of an uncertain future, Dan created a new culture that was linked to past success, which when juxtaposed to the way things had been, inspired commitment.

\section{The invisible was made visible}

The visibility of the crisis to all employees contributed to achieving commitment to make and sustain changes. While the previous management created financial improvements, it hid what soon became a painful reality. They had revitalized a 
quintessential mass production company. The company had record sales and record production. Long production runs had made them efficient. Piece-production incentive bonuses lined operators' pockets as they never had before.

When the improvement programs started, it was soon apparent that Ariens had problems. Its operations were based on 300 yard-long assembly lines and long, efficient product runs. Everyone was very busy, and everywhere they looked there were stacks of products or materials to build them with. When distributors returned the inventory they held, the stacks went beyond the factory itself, out into a secure area they set up in the company parking lot, and into the empty lots across the town of Brillion, Wisconsin. One-hundred-and-fourteen tractor truck trailers packed with products filled these lots. The managers all knew this number well. It was not only a seriously bad situation, but also much worse than the board had envisioned. As one operations manager described, "It was a come to Jesus moment." Finally, its bank fired them. They found a new lending institution, and with it the bankers' warning, "You are terrible! You'd better fix this or else!" Yet, only part of the crisis was visible to employees. According to Dan, "the financial guys at the bank...well, fortunately they trusted I understood what was going on. Otherwise, we would have been shut down. We had a burning platform." The inventory crisis was apparent, but other crucial problems, like the financial situation, remained invisible to most employees. Top management realized the need to make the crisis clear in all ways to all employees. Under previous family leadership, company financials were not shared. Employees were under the impression that Ariens was "making money hand over fist!" The company began to share its financial results with all the employees. At first workers were incredulous, thinking that management was lying about financials because the results were so catastrophic. With some extra effort, 
which included identifying and educating influential employees on financial literacy, people were convinced that these were indeed real results.

\section{True believers led the change}

Dan brought with him a strong sense of his family business' culture. As a family member, people identified him with the business, and he combined that identity with a charismatic personality to confidently set forth a credible and compelling vision. As the adage goes, you must believe in what you sell. Dan was active in making changes, and learned to believe in lean. He communicated that the company's core values and lean were the answer to its problems. Employees at all levels recognized that "Dan is an absolute believer" and they acknowledged that "one of the reasons that lean was successful was because of how management believed in it." One middle manager reported, "I've been in a lot of lean environments, and there is a lot happening here at a faster pace than I normally see because of the top support...it is like Disneyland [for a lean expert] coming here."

Employees witnessed Dan and other top managers dedicate entire days to involve themselves intimately in lean events. Top management anticipated there would be push back and expected that it would take between one and a half and three years for the employees to be convinced that they were serious - lean wasn't just a flavor of the month. Many of the decisions that top managers made were difficult, but they had to stick with them. One of the hardest efforts was in changing the piece-part rate bonus payments. How could a company become lean if it continued to give workers financial incentives to produce over needed inventory? The senior manager that implemented the new pay rates met with all employees to explain them, and adjusted salaries on an individual basis so that workers were not paid less. 
As they embarked on their lean effort, Dan went to the manufacturing floor and humbly explained that he was not an engineer and that he did not have all the solutions. He ended by saying, "You guys know, not me." One manager expressed, "you see people on teams that are empowered, they're ready to make their decisions... one of the ten rules that they have at that Monday event is that everyone is empowered."

Within a three-year period, many Ariens employees became lean proponents, referring to themselves as lean "converts." "I'm a convert - now I believe it. I see things that now take weeks and months that used to take months and years." The positive zealousy and results were undeniable and the enthusiasm around lean was contagious. "To see the work-flow improvement was amazing to see. There was almost a cult-like following around these kaizen ${ }^{3}$ events." Those who are part of lean events were willing to come in on Saturdays, work after hours, and take their workload home. Despite this time commitment "it wasn't too hard to get participation."

\section{Trust in leadership}

Dan Ariens' ability to shed light on the severity of the crisis, convey his belief in lean, and his confidence in his workforce renewed trust for upper management. In a small Midwest town where everyone not only knows everyone else, but they know their parents and grandparents, developing and maintaining trust to keep historical relationships intact was important. Trust was retained and built, because without it, the rapid progress in lean would not have been possible.

Upper management had to convince everyone from the shop floor workers to the board to give lean a try. There was resistance from all directions. A lean consultant described the resistance of one manager this way: "it was like dragging him through mud.” Many employees reacted with a skeptical “Ah, yes, we'll do whatever you want, 
whatever it is, it's just another program." However, employees pushed through their emotional responses and, despite many of them not understanding what lean was, they did what they were asked to do. To no one's surprise, the early kaizens were rough going. People needed to be told the importance of making the change to lean, retold and told again as they were coached through making improvements. The two operations managers met with every employee on a one-on-one basis to do what was fair, making sure that everyone was well treated. Slowly they began to see changes and positive results. Trust deepened.

\section{Flexibility and perseverance enabled Ariens to adapt to bumps in the road}

Initial efforts in 1999 to implement lean proved to be challenging. Ariens worked with trainers hired through a state-sponsored manufacturing extension program. These trainers were good at teaching ideas in the classroom, but when it came to events on the factory floor, it was not their strength. At the start of its lean effort, Ariens put onehundred employees through lean training. When these employees went to do a lean event on the shop floor they ended up "fumbling" and never made any changes.

The previous regime of command-and-control management, combined with the pressure for quick action employee and incentive pay changes, led to gathering dissent. An active effort to unionize the workforce was initiated. Keeping the workers busy required taking on contract manufacturing work, diluting the focus to the core business. Diversification initiatives created new challenges - while they could make other products, gaining access to new markets and distribution proved difficult. These efforts were all false starts many of them serious enough to derail the overall progress, but Ariens was able to persevere through these bumps on its road to improvement. The "thinking, learning, problem solving" culture that valued learning by doing and continuous improvement 
provided a resolve needed to survive these challenges. Starting over, re-designing, and trying yet once again were an expected part of doing business.

\section{Continual Improvement: Initial changes created benefits and set off a virtuous learning cycle}

If you had fallen asleep at the Ariens factory in Brillion, Wisconsin in 1998, you would not recognize what you saw when you woke up in 2005. Managers and workers had organized the factories very differently. Fifteen product lines organized into forty cells replaced the four long assembly lines. The MRP system no longer scheduled production (it was still used to forecast material needs). Linking the cells were

supermarkets, ${ }^{4}$ holding parts and subassemblies. The upstream cell saw what it needed to build to replenish the supermarket inventory. Parts going to cells were stocked every one or two hours, making it possible for a cell to switch to a different model up to eight times in a shift. The factory could make any product to demand at any time of year; gone were the twice-annual factory changeovers. A single big bang did not create these dramatic changes; it took accumulated alterations over five years and six-hundred employee-driven improvement projects.

Ariens' early efforts started small and resulted in little changes that created some benefit. Initial benefits instilled confidence, and enabled ongoing efforts. Small successes built upon themselves by encouraging new efforts, and the continuing changes accumulated into dramatic improvements. Executives made sure that they did not confine lean efforts to only manufacturing areas, but included all functions, such as engineering, administration, finance, and customer service. They asserted that if lean was to have an impact on their organization, it would have to be applied to every aspect of the business. Every member of the management team learned about lean and led 
improvements in their functional areas. Results were also not confined to business benefits; people at all levels had to learn, grow and become more competent to make these improvements. Over time, the lean improvement required a broad restructuring that provided an alignment of reporting relationships to product value streams. These changes contributed to a series of multifaceted business outcomes and personal results that further reinforced progress.

\section{Initial tangible changes showed that this effort was different}

Ariens needed to make many changes to stay in business. Senior managers made strategic and financial restructuring changes. They built on long-standing relationships with the financial community to renegotiate loans and lines of credit. They changed their distribution system, cutting out the cost of distributors, to sell directly to dealers. They created dealer service and support organizations. They converted assembly lines into manufacturing cells, and streamlined all operations. These changes required leadership at many levels.

Lean efforts began in 1999 with a number of isolated efforts. Ariens hired managers with lean experience, experts with lean knowledge, outside trainers, and engaged Simpler Consulting to lead improvement events. From their initial value stream map, the executive team identified improvement projects. The priorities for selecting these efforts were willing managers and opportunities for "easy victories." The first two projects were in a gear case assembly and customer service. In the first case, the gear case cell was reconfigured; it went from 18 people making 100 pieces per month to 4 people making 500 pieces per month. Customer service, an order-entry office operation, applied lean approaches beyond manufacturing. The experiences from these initial efforts were used as examples in approaching other areas and spreading lean. 
Previously, it took two weeks of down time and cost upwards of a million dollars to switch the factory over seasonally from lawn mowers to snow blowers. Costs were incurred while nothing was produced, and there were periods of inefficiency as the new line started up. Then there were seasonal peak production periods, requiring Ariens to hire temporary production workers. Production lines required building products to forecasted volumes and warehousing finished products to be ready the upcoming season. Forecasts were never accurate, especially when based upon the weather, which is what drives snow blower demand. In the winter, when the productions lines were producing lawn mowers for the summer season, it often happened that Ariens would suddenly need to build more snow blowers. Many things changed with lean. Before starting, managers determined the needed size of the workforce. There would be no layoffs from lean improvements. When improvements change the number of people needed, they are reassigned to new jobs. Cells enable making any product at nearly any time. Efforts are made to look out 12 to 18 months to forecast market needs, and level the production load to avoid swings in the needed workforce. As production volumes have increased, lean methods have become increasingly critical in improving efficiency to keep up with new demand.

Changes were not limited to production. Payroll processing used lean concepts to reduce its needed staff by fifty-percent in four years. In overall administrative areas, the employment had been constant while sales doubled and the number of transactions per order increased. Invoicing previously required three people; after lean was implemented, it was done as one person's half time responsibility. There had been eighteen people in customer service, after lean it was done at the same service levels with just six. These improvements were possible by reorganizing work processes along with other changes, 
including new information technology support. For example, clerks used to do the invoicing by mailing paper statements. After lean, they emailed and imaged invoices instead of working with paper copies. As the workload changed, people went on to other work and jobs. For instance, instead of relying on outside contractors to install a new powder-coating system in one of its plants, Ariens used it own employees to complete the job. No one has ever been laid off because of lean improvements.

\section{Lean success became evident through the multi-faceted outcomes of business and personal results}

At the center of Ariens' improvement effort was its success. Nothing is as

successful as success itself, and there was success at many levels for customers, suppliers, investors, owners, workers and the community. People felt empowered, there was broad and regular involvement in improvement efforts. In fact, in four years of lean activities, over six hundred kaizen events took place, with over half the workforce directly involved in these efforts. Lean was not confined to lower and middle levels in the manufacturing organization. Senior managers from all functions planned, led and participated in lean efforts.

Those we talked with during our visit said that there were changes in how management listened to employees, and lean had provided for job enrichment, particularly, it seems, from people who became lean interns. We heard interns talk about their training in lean affected seeing waste - even when they were shopping at the store. It also taught them that they could do something about it, and that their efforts would make for a better place to work. What this provided was a workplace where "you can stay and grow... that's the real opportunity at Ariens, rather than going someplace else." 
Inventory turns and productivity improved by many multiples, improvement project requests were readily funded, and the company operated so that it produced cash as it grew.

One of the important outcomes of its lean transformation was the growth in Ariens' business. Growth came from the company increasing its market share on every product line. Customers saw Ariens' products as having more features and better quality for the same price as competitors offered. Cumulatively, these changes enabled Ariens to access new markets. The restructuring of its distribution system enabled the company to price products more competitively. The pricing structure, along with a new product design, enabled them to hit the needed under one-thousand dollar price to sell snow blowers through Home Depot.

Extra capacity allowed Ariens to "insource" production. For example, quality problems with the welding of hex nuts on a shaft had them bring that production in house. Supplier problems with the quality of the gear led to the development of a new design that was produced internally. When purchasing determined that it could source a spindle that was costing \$31 to make internally for \$19 in China, a kaizen team redesigned the spindle and its production to provide it at just over $\$ 15$ internally.

The restructuring of manufacturing operations also enabled multiple changes. Manufacturing floor space decreased $40 \%$ in five years, and travel distances for products decreased $90 \%$, while the output doubled. Cells moved so that related product lines were located near one another. One of four plants became a company museum, and another freed up sufficient space to relocate engineering there. 


\section{Greater benefits came from aligning to value streams}

Dan Ariens led many of the initial changes. He made day-to-day decisions as he worked to realign the organization, bring in a new management team, and restructure the distribution system and the company's debt. The lean efforts produced results in better production efficiencies while they highlighted new opportunities. After three years and over two-hundred improvement events, management restructured reporting relationships to take full advantage of lean approaches. Ariens was organized in functional departments, such as engineering, purchasing, manufacturing, and finance. This reporting structure did not serve them well in improving as a value stream.

In 2003, Ariens reorganized into nine major value streams reporting to two operations vice presidents. Moving to value streams as a central organizing principle helped focus improvement efforts to product and customer needs. The value stream managers were accountable for both ongoing operations and incremental improvement activities. The people from traditional functional units moved to the value stream teams.

\section{Lean Change Methods: Leaders setting goals, communicating, and giving feedback changed the culture}

One of the important challenges for executives was Ariens' business focus. To reach pricing targets and new markets, they could not afford the $20 \%$ cost of selling their products through distributors. Ariens needed to sell directly to dealers. The company also dealt with too many suppliers, and went from over eight-hundred to about twohundred suppliers. During this time the company focused on it core business, and ended the contract manufacturing business it had created to utilize extra factory capacity. Lean principles created the framework for improvements, and implementing these changes made the focus for the new leadership team clear. 


\section{Lean created structure for continuous change}

Lean is a set of tools and methods that enables people to think about themselves, their work, the relationship of their work to those they depend upon and those that depend on them, and ways that they could together improve what they do to eliminate waste and create more customer value.

The essence of the lean efforts at Ariens is multiple small improvement teams working in week-long events. Events had specified pre-conditions, timetables, memberships and follow-up activities. Detailed boxes of forms for every occasion of lean tool and event were available in Ariens' conference rooms. At one level, these were onerous and inflexible details. Yet, as we listened to what people told us, the rigid process created enormous flexibility. With lean tools, people collected, depicted, and analyzed data on their work processes in standard ways that taught new skills and a symbolic system, or language, to understand one another's roles. Over time, the information collection, depiction, and reporting processes enabled rapid and continuous improvement across the organization. For example, daily briefings at a specific time at lean team events according to standardized formats made it possible for senior leaders to attend, listen, support and provide their authority to carry changes forward. Lean provided a structure and discipline to develop improvements, follow through, and make changes. In making those changes, lean created a company that was both more rigid and more flexible.

\section{Upgrading people \& creating new roles}

As these changes were made, new, up-graded management-team-level executives in manufacturing, finance, and administration were recruited. Ariens had to effectively deliver value to its dealers and customers while competing against companies from across 
the globe. Previously, two strong, seasoned managers had run manufacturing. As the company organized efforts by value streams, it needed nine strong managers to run those value streams. Ariens had to bring those new managers up in terms of their skills to run those businesses. Restructuring the organization into value streams was an essential part of lean, and one that was handled with caution. The manager responsible for the value stream was in a key position, and if the person in that role was not right, it was a recipe for a business disaster.

To be confident in their delivery capability, value stream managers needed to work with Ariens' assembly workforce to ensure it was operating as effectively as possible in its ability to deliver value. They also worked with design and engineering to improve their products based on their knowledge of what customers wanted. In addition to meeting their operational and financial goals, value stream managers had to make ten to twenty percent annual improvement targets. These goal required metrics to capture performance and provide feedback on improvement progress. The value stream managers ran their businesses at world-class performance levels and made ongoing improvements because their efforts were embedded in a larger organizational system that was capable and supportive of lean initiatives.

\section{Cultural change}

When visiting Ariens, it was easy to be impressed by many lean activities and supportive behaviors at all levels of the organization. These were indeed indicators of successful lean change efforts. There were also indicators of deeper, more fundamental changes in the way that people thought and talked, particularly, about change itself. These latter changes were indications of a new, developing culture, one that supported 
growth and continuous improvement across all levels of the organization and reflected a growing acceptance of lean.

Individuals who had led change efforts described the reception they got to proposed changes depended upon how they presented those changes. If they communicated well and let people be part of the change, the people were much more receptive. One of the lean interns described how she had suggested several changes years ago, but the management from that time did not listen. Now these changes have been integrated into how the company does business. The managers listened to people, and people no longer hesitated to provide their ideas.

There had been no layoffs since Ariens started lean. Some employees had left voluntarily, and others left because they did not want to make the needed changes. People readily got involved in improvement efforts, and there was good teamwork. They appreciated extra pay for their performance and improvement. People knew how they were doing on their own goals and, from quarterly meetings, how the company was performing as a whole.

\section{What is next?}

If, as some management books propose, one of the principles of lean is the continuous pursuit of perfection, ${ }^{5}$ then Ariens readily embraced that goal. Among senior managers there was less talk of what had been accomplished and more focus on what still needed to be done. "We're still not successful, we're doing better now, but we have not driven success yet over the long haul.” The remaining challenges included gaining broader and deeper acceptance by the workforce. As positive as the story of improvement and change was at Ariens, it was not without its skeptics and opponents. Change became a regular way of life at Ariens, but it was still never comfortable. Ariens 
employees struggled at times with change. Employees tried to throw back to management some of the new responsibilities that had trickled down. There were still some that complained. Some employees voiced skeptical views on management's motives to get people to work harder.

Managers talked about an ideal lean world where workers would make improvements without the deliberate efforts involved in special "lean events." Everyone would see through a lens that highlighted waste and every person would take on the responsibility to make improvements. While the Ariens culture had moved in this direction, the utopian vision was still to be reached. Employees were taking initiative, recognizing waste, and aware that waiting for events to make improvement was itself wasteful. They continued to depend upon consultants for direction on lean events.

Like any organization implementing lean, one of the largest challenges Ariens faced was its ability to convince other organizations in its value stream to adopt lean. To maximize the benefits of lean across the enterprise, each organization needed to become committed to lean. Ariens had begun to teach lean to its suppliers, dealers and end-users, helping them to become more efficient, and profitable, in their service and retail operations. But, for complete enterprise change to occur, these companies would need to lead in their own lean transformation. While progress had been made to sustain leanprinciple based transformations, Ariens had large challenges still before it.

One of the questions that Ariens asked was for us to judge in our case study efforts how they are doing in their lean transformation. Our findings have been very positive, and the efforts that they have made are well targeted and have yielded expected results. Many companies that undertake lean get to the point of seeing themselves ahead of competitors, and then relax a bit. Lean, as a philosophy, is not about just doing better 
than competitors. Certainly, that is important because competitive markets require companies to have products and service at good prices, performance and quality levels. However, a lean philosophy like the one we heard from many of the people we interviewed at Ariens is about continually looking for opportunities. One level of performance will certainly still have opportunities, opportunities to find and eliminate waste or improve value delivery.

While they acknowledged their progress, they also spoke to their infancy in their lean journey and indicated their lack of satisfaction with the progress made to date. Completing his last interview with us, Dan gazed past us as he reflected on all the lean strategies underway at Ariens. He then abruptly snapped his attention back to us and stated, "but we are not successful yet!" 


\section{Appendix A Comparative Financial \& Operational Results}

As a privately held company, Ariens does not publicly report financial and operational results. While we have had access to this data to confirm that their lean efforts have produced results at organizational levels, we are not able to provide any of these details. The normalized comparison of performance measures (see Figure 1 in case) used Ariens' data to show the relative improvement results. These results were consistent, in timing and magnitude, with what was described in interviews with executives. Those results can be summarized, for the six years of Ariens' lean transformation (from 1999 to 2005), as follows:

- revenue has doubled,

- profitability, initially a loss, has increased more than fivefold,

- productivity, as measured by cost of goods sold divided by the number of employees, has more than doubled,

- other operational improvements include:

$\circ$ inventory turns increased threefold

- safety incidents, which initially increased, dropped 20\% from 1999 levels (and were half their 2001 peak levels)

These improvements are all relative to Ariens' efforts in 1999. We also undertook a comparison of Ariens' results relative to firms that made products similar to what Ariens produced. We used data that was publicly reported from large corporations. Both of the comparison companies, which Ariens' management asked us not to name, were orders of magnitude larger. Hence, the comparison also includes other businesses, and make larger product lines. Again, respecting Ariens' management's wishes, we are not reporting absolute or relative numbers, although the numbers were used in our analysis. What we found was quite interesting. 
In the 1999 to 2005 period, Ariens improved more than the two large companies did. In part, that rate of improvement was due to Ariens' profitability being lower than these other companies in 1999. In 2004, Ariens' profit margins were on par with these larger competitors. With the investments Ariens made in its facilities, development of its dealer relationships, and ongoing improvement efforts, we expect Ariens' results to exceed those of these larger companies in future years.

\begin{tabular}{|l|}
\hline Revenue \\
Pretax Profit \\
\\
Productivity \\
(COGS/FTE) \\
Inventory \\
turns \\
Safety \\
(OSHA \\
recordable)
\end{tabular}

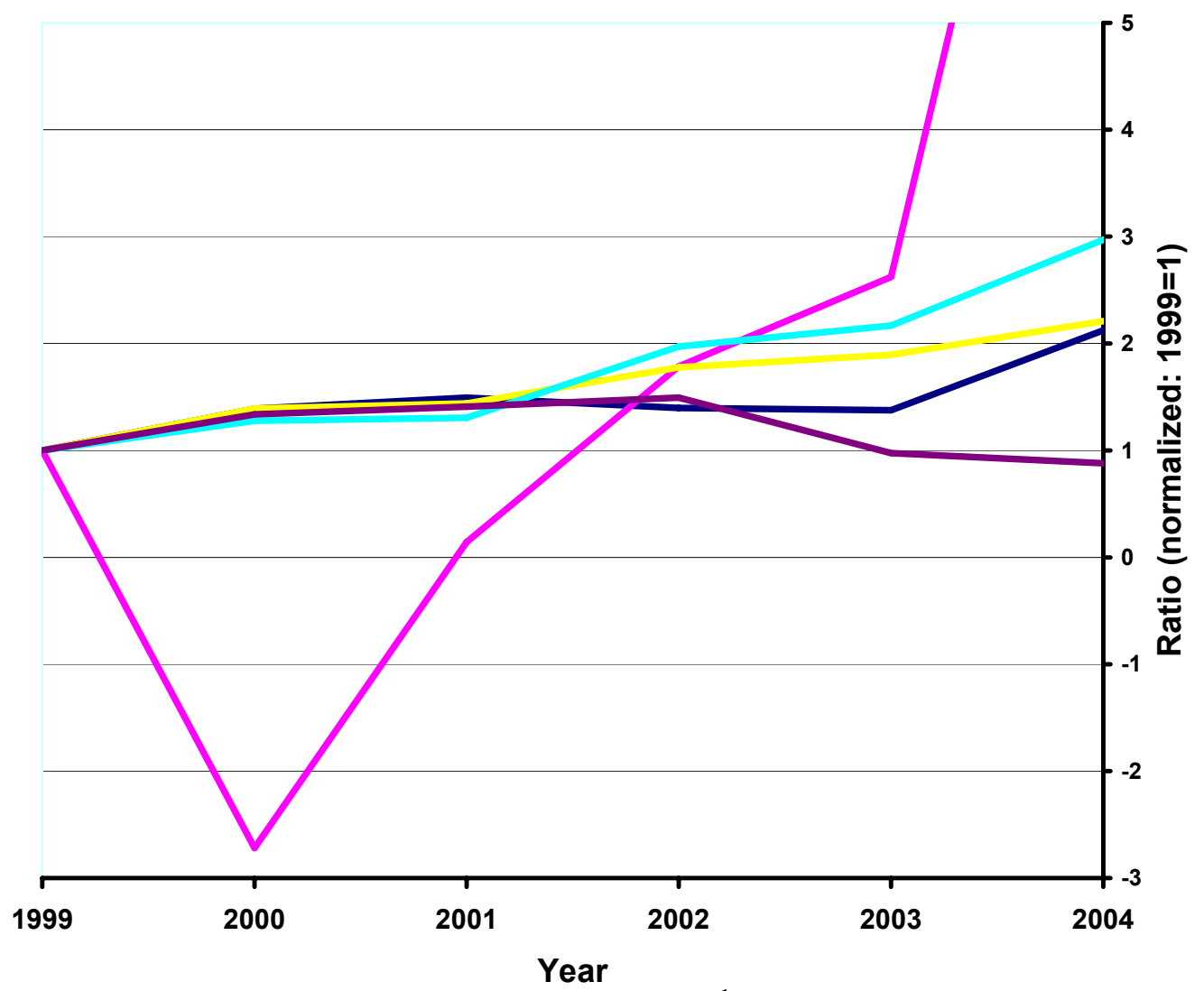

Figure 1. Ariens Performance Metrics ${ }^{1}$

\footnotetext{
${ }^{1}$ Ariens is a privately held company and does not publicly release financial and operational information. The metrics in this graph are taken from internal reports and normalized on 1999 levels. They show significant financial and operational performance improvement in the five years that lean transformation has been underway.
} 


\section{Appendix B Ariens Company History}

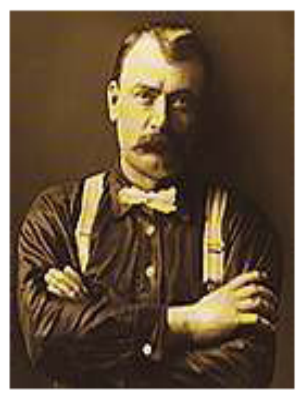

1893

Henry and Christine Ariens settled in Wisconsin, bringing the metal working industry to Brillion. Brillion Iron was founded in their garage.

The company made continual progress and in 1900 , built a new plant in a new location.
Henry's eldest son, Mando "Steve" Ariens, took over Brillion Iron. Using his metallurgical expertise, he leads Brillion Iron in becoming a major contributor in ductile iron casting technology.

1929

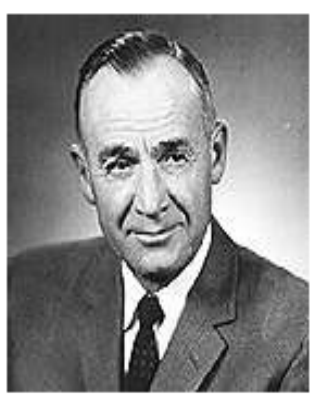

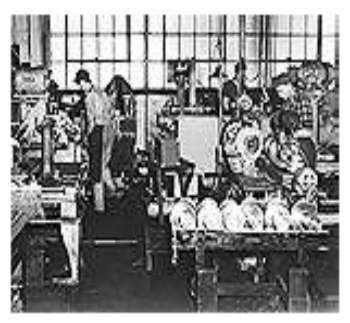

1932

In spite of early success, Brillion Iron was among many businesses to suffer financial difficulty during the "Great Depression." The company declared voluntary bankruptcy in 1932.

It marked the end of an era, but also an exciting new beginning.
Even with the country in the throes of depression, a new business, the Ariens Company, was born in Henry Ariens' garage and Steve Ariens' basement. The first Ariens Rotary Tiller, a 30" tiller, powered by a front-mounted fourcylinder, V-type, $14 \mathrm{hp}$ engine was developed.

1933

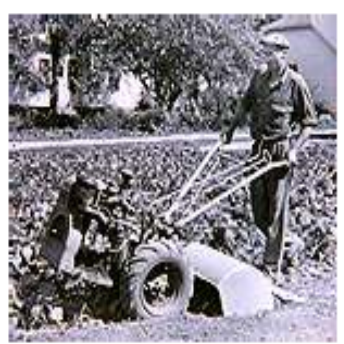




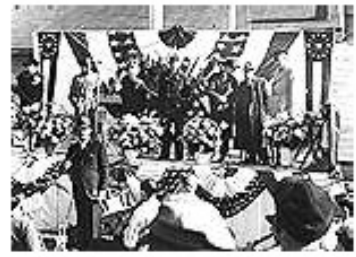

1945

Ariens is awarded the Army

Ordinance Award for crisis

manufacturing shell casings

and other materials for

World War II battles.
Three consumer products, the "Jet Tiller", the first œnsumer Rear Tine Tiller and the Imperial Riding Mower, help to establish

Ariens as a major

manufacturer of lawn and

garden equipment.

\section{$1950 \mathrm{~s}$}

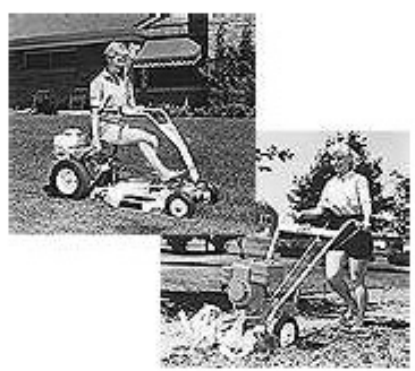

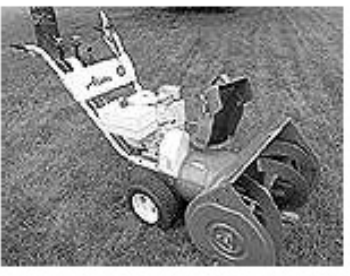

1960

The two-stage self-

propelled snow-thrower is developed.
A new 23,000 square foot plant is built.

\section{3}

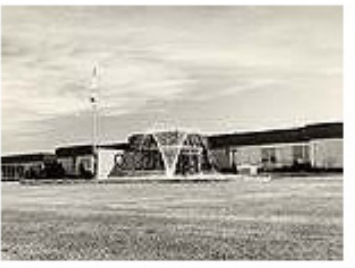




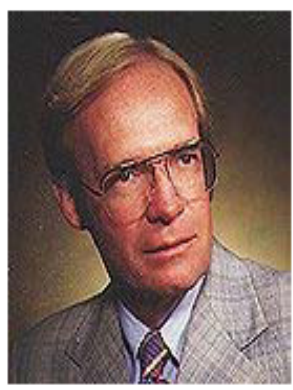

1969

Michael Ariens becomes company president as his father, Steve Ariens becomes chairman of the board.
Acquisition of New Holland Company lawn and garden division allows the development of the lawn and garden tractor line.

\section{4}

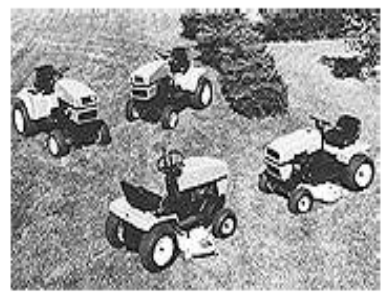

Ariens aoquired the Gravely Company, a North Carolina manufacturer, who had a proud history dating back to 1926. A new product line of commercial lawn care products designed and marketed as a result of that acquisition.

1977

1982

A new fabrication plant is built, bringing total manufacturing space to 600,000 square feet, sixteen-hundred times the size of Henry Ariens' garage!

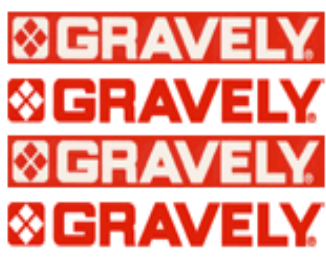




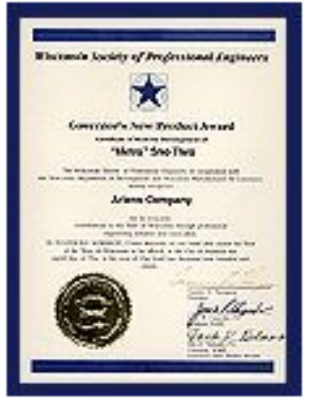

1983

Receives the Governor's New Product Award for the 21" Walk-Behind Lawn Mower and the HT 16 Tractor.

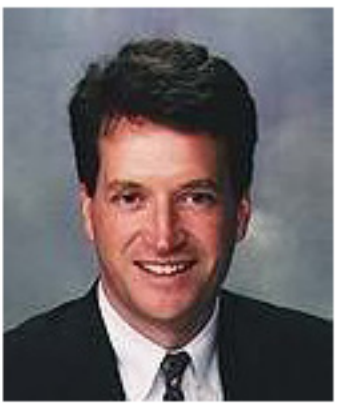

1998

The fourth generation assumes leadership as Daniel Ariens becomes president of Ariens Company and brother, Peter Ariens, becomes president of Stens.

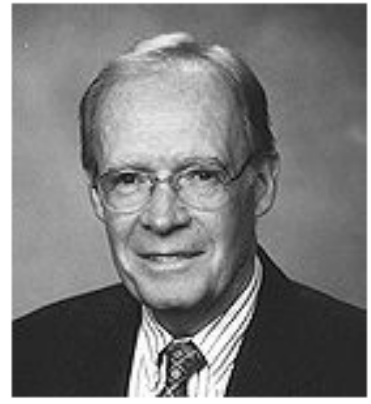

1992

Michael Ariens is appointed Chairman of the Board and David Vander Zanden becomes president.
Aoquisition of S Corporation, an parts marketer.

\section{5}

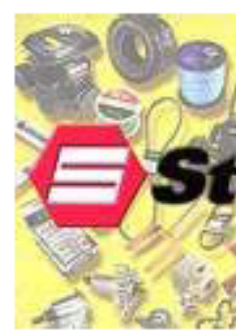




\title{
Doing More with Less at Ariens: A leadership and transformation case study
}

\section{Teaching Notes (draft)}

\begin{abstract}
This case study illustrates the challenges of organizational change and transformation. The company studied, Ariens Company, used "lean" principles and methods in making these changes. As a manufacturer of snow and lawn equipment, the promises of lean manufacturing from the automotive industry were very appealing to Ariens' management. Indeed, the company faced a crisis in 1998 - overproduction had left it with excessive inventory, and its costs were too high to sell its products through retail channels. Distribution costs ate most of the possible profit margins in selling through dealers. The company needed sweeping changes - a financial restructuring, change in its distribution system, reduction of inventory, new production methods, and lower cost and better quality products. The company as a whole, from senior leadership to shop floor workers, needed to work together to achieve these changes. The thinking, process and sequence of top, middle and front-line management changes, is the focus for this case study of lean transformation.

In June 2005, we made a three-day visit to Ariens where we formally interviewed eleven people - from the CEO to factory workers. We also toured the plant, attended a lean meeting, engaged in many informal discussions, and reviewed secondary sources. Three themes were derived from the data and illustrate what we learned studying Ariens' lean program. This case is important for managers and students studying organizational change, leadership, or lean manufacturing because it provides an example of a set of
\end{abstract}


changes, using and extending lean manufacturing principles, which accumulated into significant performance improvements and from which all managers and students could learn.

\section{Teaching Objectives}

This case develops students' abilities to:

1. Recognize the challenges for domestic US manufacturing companies, particularly vertically integrated firms, as they respond to internal and external environmental pressures to change.

2. Identify effective leadership qualities and behaviors that influence change.

3. Become familiar with the concept of lean as a technical methodology for analysis and change

- And, consider concepts of quality (TQM, TPM and Six Sigma) and bottlenecks (critical chain) methods

4. Discover the key complement of context, process and leadership for making and sustaining improvement and change

- Recognizing the importance of going beyond implementing change to creating a system of change that is and can be sustained

$\circ$ Distinguishing planned change from continuous improvement and organizational learning

\section{Course}

This case is intended to be used in a Masters level course in Change Management, Leadership, or Lean Manufacturing. It addresses the social and human elements of change, more so than the technical tools. The case for change in American industry is well known, but why do so many companies struggle in making and sustaining these changes? Examining what was needed to instill and sustain change at Ariens helps students understand these challenges.

This case can be taught by taking two perspectives:

1) Management team - as a member of the management team, what are the responsibilities and areas of focus for management's attention.

2) Employee - as a supervisor or middle manager in Ariens, how do the changes and management efforts affect you and your responsibilities? What is your role in promoting improvement and change?

There is sufficient detail about the nature of change for students to consider and discuss middle management positions and roles in an overall organizational change initiative, like 
the one that has taken place at Ariens. There are important lessons about support and participation in these efforts that are necessary at these levels, which the case discussion can bring out.

\section{Lecture or context to precede Ariens Case:}

- Competitiveness in Manufacturing \& Lean Manufacturing

Dertouzous, M., R. Lester and R. Solow 1989 Made in America: regaining the productive edge Cambridge, Mass.: MIT Press.

Womack, J., D. Jones and D. Roos 1990 The Machine that Changed the World, New York: MacMillan.

Womack, J. and D. Jones, 1996 Lean thinking: banish waste and create wealth in your corporation New York: Free Press.

Dyer, J. 2000 Collaborative advantage: winning through extended enterprise supplier networks. Oxford; New York: Oxford University

Case Discussion: [Dear Reviewers: Providing thorough answers to the following case discussion questions was un-doable given the Case Conference deadline. However, we are presently crafting our answers and will provide them to you in the next two months. We would like to ask that our case not be excluded from consideration as a recipient of a "best case study" award if you otherwise deem it appropriate. Thank you for your consideration.]

The case study is written in three themes, each of which contains important topics for the process of change and improvement around lean methods. The authors derived these themes using grounded theory techniques for qualitative data analysis. The interviews were coded for key concepts discussed in the use of lean and associated changes. We found patterns and related concepts and sorted them into groups. These groups were then described through the development of theme statements. We continued to develop groupings and themes until we had included all concepts. Once the themes were developed, we sorted interview comments in them, also using the concepts and groupings associated with themes. The interview data, as well as secondary source material, and requests for quantitative data for operational and financial performance, were the basis for writing this case study. 
The three themes then became the organization through which we present lean efforts and changes at Ariens. Teaching this case can involve interactive discussions around these themes. Suggested introductions and opening questions for these discussions follow. 


\section{Background, history and time line}

Discuss medium sized manufacturing business. What experiences have students had in working in these firms?

What jobs have they held?

What were the working conditions like for those that worked on the shop floor, in fabrication or assembly?

When did they work at those companies? What has happened to their companies since they worked there?

What are the pressures facing medium sized (and all) manufacturing firms in the US?

Set context for Ariens being a typical family-owned, successful manufacturing business making snow blowers and lawnmowers. Use the company web site to show the range of products produced today. Use the company history to show the legacy of the company in its business, as well as the local community where it operates. Show time line of lean transformation (see Figure 1) - to set the broad context for the case discussion.

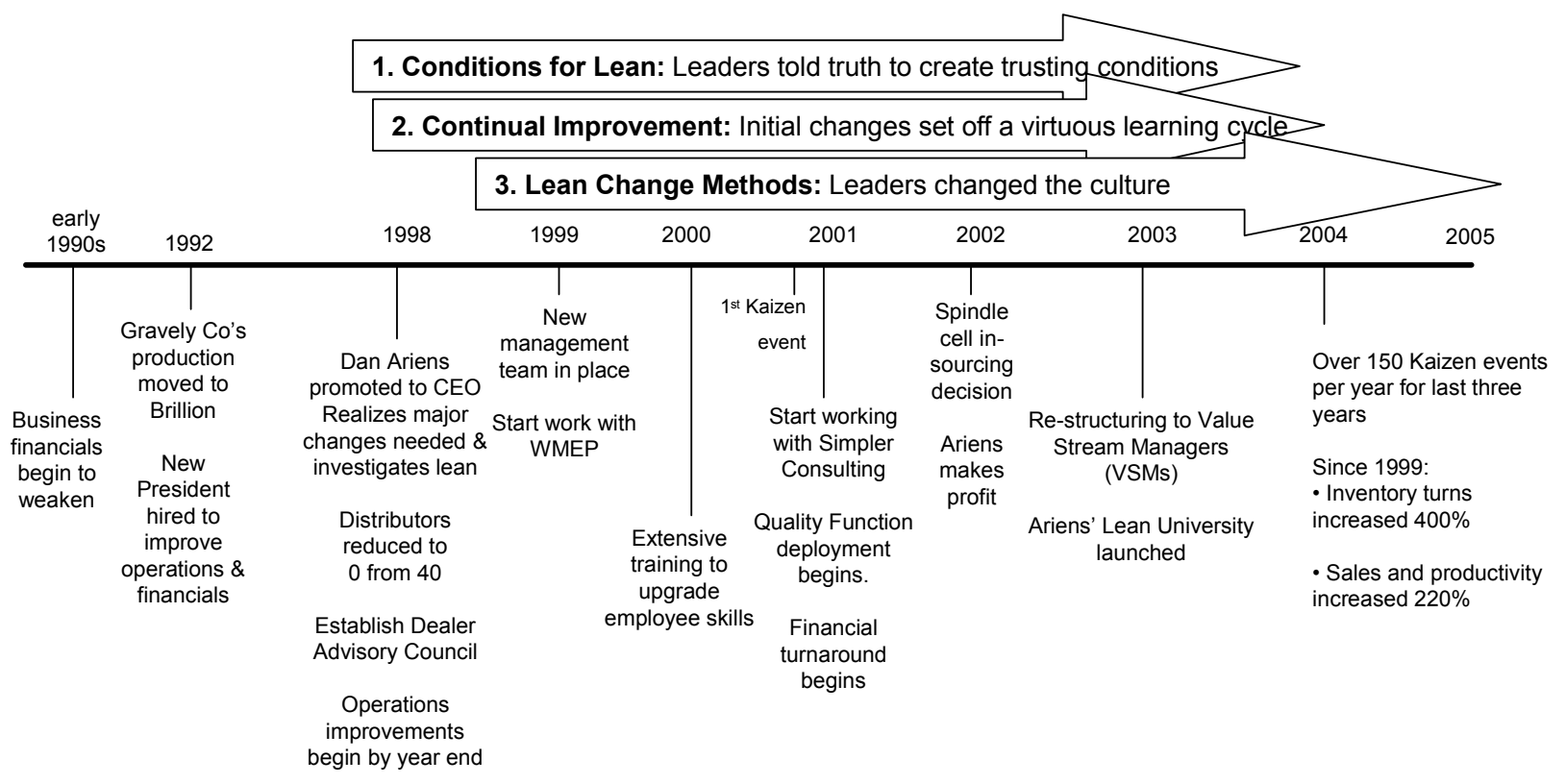

Figure 1. Mapping of case study themes on time line of Ariens' lean transformation milestones. 


\section{Conditions for lean}

What was the situation that the Ariens President faced when he moved back to Brillion to take over the company?

What had made the situation much worse than Dan Ariens had expected, which didn't come out until he looked into the details?

Given his situation, why was Dan Ariens attracted to the ideas and concepts surrounding lean manufacturing?

What were his initial actions, and why did they make sense as first steps? What were the limitations of these actions? When were these limitations realized, and what corrective actions were taken?

\section{Continual improvement}

What contributed to the succession of efforts that was part of the adoption and implementation of lean at Ariens?

If you were to look at Ariens when it started Lean, in 1998, and then only again in 2005, how would you characterize the changes that you see?

What is the difference between continual change and radical transformation?

We often look at change based on what we can observe and measure. What changes, beyond those that are observable and measurable, took place at Ariens?

$<$ develop a list based on student responses $>$

Are these changes desirable? Which ones? What can you do to manage the desirable changes? What can you do to avoid the undesirable changes?

\section{Leadership for change}

What does an organization need to do if it wants to expand from the use of lean tools to the ongoing implementation of improvements?

What are the requirements of leadership in leading and implementing change around lean principles and methods? Discuss these requirements in terms of how they impact the following roles:

1) executive level managers

2) middle managers, and

3) front line supervisors

How are these leadership requirements similar and different from:

1) traditional operational management?

2) management of planned change? 


\section{What is next?}

Having reviewed and discussed what it has taken for Ariens to achieve its current success, the case moves into the future, and invites the student to think about what he or she would do next.

The following questions facilitate that discussion:

1. When you read this case, and compare it to other cases or experiences of organizational transformation or lean change you are familiar with, in what ways is this case similar, and in what ways is it different? Which of those similarities and differences explain differences in the outcomes at Ariens versus the other cases?

2. List the different stakeholder groups involved in Ariens' lean changes. What are each of their interests, and how were these interests addressed through the lean change efforts?

3. Most organizations want to do more that just change from where they currently are to a new and better state. They want to build, as they improve and change, the capacity for future improvements and change.

What has Ariens done in its current lean efforts to encourage and enable future changes?

What issues must Ariens address if it is to continue its improvement?

Should Ariens be satisfied with its current progress and achievements? Why or why not?

4. What would you do if you woke up tomorrow and found yourself in:

1) Dan Ariens' position?

2) the role of one of the product life cycle managers?

3) a front line supervisor in assembly at Ariens?

4) a worker on the line at Ariens?

5) a broker asked to recommend whether or not to purchase Ariens stock?

5. You are interviewing for a job at Ariens, and given your good education and knowledge of lean, you are invited back for a second round of interviews. You have 15 minutes with Dan Ariens, and he asks you, "how do you think we are doing, and what do you advise that we do next?" Be totally honest and truthful in your answer, you know that is the culture Dan wants to create, and you realize your ability to have some key insights is what will determine whether you will get the job offer that you want or not. 


\section{Closing Comments}

While many people focus on the implementation of lean tools and methods and the extent to which these tools are utilized throughout organizations, they are but indicators of a more fundamental, human process. Individual learning and a capability to learn collectively are the underlying processes needed for change to be successful and sustained. When Ariens' managers teach and use lean tools, they provide new insights from performance data. Those insights are the basis for making improvements, and the data on performance provides feedback on the progress of their efforts. As described in Theme 2, "Continual Improvement," the cycle of setting expectations, trying new approaches, collecting data, making changes, assessing outcomes relative to expectations and making adjustment is an organizational learning process. In Themes 1 and 3, "Conditions for Lean," and "Lean Change Methods," the application of that learning cycle shows that the organization needs openness and trust. It is that which enables making data visible to provide feedback on expectations, activities, and results, as well as full engagement of the organization's leaders and workforce in the process of making and sustaining improvements.

Ariens' lean implementation follows strictly defined tangible steps and procedures. These procedures increase communication across levels in the organization by requiring various levels of management to listen carefully to production workers. Employees, trained to see waste, are encouraged to communicate what they see. The strict procedures also lead to the feeling of empowerment and opportunity amongst employees by requiring teams, as opposed to individuals, to make important decisions. The new way work is organized enables 
teams to respond quickly to make the needed changes. In essence, as described in Theme 3, lean's rigidity provides the flexibility critical to continuous improvement and the success of lean at Ariens. 


\section{Endnotes}

${ }^{1}$ See Womack, J., D. Jones and D. Roos 1990 The Machine that Changed the World, New York: MacMillan for details on definitions of lean, and Womack, J. and D. Jones, 1996 Lean thinking: banish waste and create wealth in your corporation. New York: Free Press for lean principles.

2 In addition to Womack and Jones (1996), Liker, J, M. Fruin, and P. Adler. 1999 Remade in America : transplanting and transforming Japanese management systems New York: Oxford University and Liker, J. 2004 The Toyota Way: 14 Management Principles from the World's Greatest Manufacturer. New York: McGraw Hill extend lean concept beyond their original articulation.

Murman, E. et al. 2002 Lean enterprise value: insights from MIT's Lean Aerospace Initiative New York: Palgrave and Dyer, J. 2000 Collaborative advantage: winning through extended enterprise supplier networks. Oxford; New York: Oxford University extend these ideas to enterprise levels.

${ }^{3}$ Kaizen is a Japanese term meaning gradual ending improvement by doing little things better and setting and achieving increasingly higher standards. (This definition is from "Lean Glossary" by S. Rooney and J. Rooney, Quality Progress, American Society for Quality, June 2005, pages 41-47).

${ }^{4}$ Supermarkets are the storage locations of parts before they go on to the next operation. Supermarkets are managed by predetermined maximum and minimum inventory levels. Each item in the plant is at a designated location. (This definition is from "Lean Glossary" by S. Rooney and J. Rooney, Quality Progress, American Society for Quality, June 2005, pages 41-47).

5 See Womack and Jones 1996, Murmon et al 2003, and Liker 2004 for ideas extending from lean in production settings. 